\title{
Educational Dominants in Vasyl Sukhomlynsky' Pedagogical Concept
}

\author{
Mariana Marusynets, Yuxiang Zhao, Nadiia Sylenko
}

The primary dominant of the educational process is the upbringing of the child's need for another person, no compulsion to live among others or collective interest, and personal needs that is close to the soul.

All the activity of the teacher was filled with the boundless faith in the child, the generosity and nobility of his/her soul, the inexhaustible wealth of intellectual and moral strength, the enormous educational opportunities that society creates. He wrote that the years of childhood were first of all the upbringing of the heart, which became its pedagogical meaning. Love for a child's heart is born in someone who is able to dispel anxiety and confusion, comfort, instill faith in their own strength; who is able to protect vulnerable, very sensitive children feelings i.e. a sense of dignity. He was convinced that empathy is a sensitive period in the formation of the child moral «I». Such moral concepts as: good and evil, justice and injustice, truth and lie, sincerity and selfishness, are manifested in the child's mind first and remain in children's emotional memories for life.

The pedagogical world of $V$. Sukhomlynsky is complex and diverse. It has constantly understood by scientists and educators of the new era. To deeply understand the teacher-thinker, it is necessary to rise above his professional impulses, to comprehend the depths of his humanistic worldview, which culminated in the pedagogy of higher wisdom i.e. the wisdom of education. His life was filled with joys and sorrows, hopes and disappointments, creative prospects and self-dissatisfaction.

Keywords: educational dominants; Vasyl Sukhomlynsky; pedagogical concept.

\section{Presentation of the main material}

The topicality of the child's personality study by V. Sukhomlynsky is due to the needs of education pedagogy and innovative technologies. The 
phenomenon of «personal education» took a leading place in the pedagogical achievements of the teacher. An example of this is one of his greatest works «Problems of the comprehensively developed personality education», in which Vasyl Sukhomlynsky did not leave to follow the formulation on the concept of «personality» due to the pedagogical prohibitions, but identified its two main features: personality is not born, you can become in the process of education. This position does not cause objectives, if to consider the social basis of the concept of «personality» as an individual who acquires certain qualities in the process of life in society (Sukhomlynsky, 1977) and personality is an individual with a sense of dignity, emphasizing the need for self-esteem education to everyone. "Without self-respect, there is no moral purity and spiritual wealth of the individual. The most important pedagogical tool for us is the ability to deeply respect the human personality in their upbringing» (Sukhomlynsky, 1977).

Immersing in the concept of «personality», the teacher points to the following features: personality lives on the scale of human charity, and human develops and educates as a subject of creative activity, in order to be happy and bring good to people. To be a real person means to give the strength of your soul in the name of the people around you to be beautiful, spiritually rich, «... for every person you meet in life, there is something good from you and your soul» (Sukhomlynsky, 1976).

In this context, the individual is a means for becoming e a real person who has a great ability to live. The path to the individual ascent is complex and long. "Only humanity, tenderness, and kindness, the simple human kindness can bring up a real person.... (Free education of VLADI VLADI: pedagogical almanac, 1993). Sukhomlynsky was convinced that every pupil should value people as the greatest value. It is possible if he himself has a sense of self-esteem, respect for others and for society. Without this, human will not be an individual, but a despiteful, unhappy creature. The primary dominant of the educational process is the upbringing of the child's need for another person, no compulsion to live among others or collective interest, and personal needs that is close to the soul. In the book «I give my heart to children» the educator notes: «... if a child does not know how to see in the eyes of another person, what is in his/her heart he/she will never become a real person» (Sukhomlynsky, 1977). And for this, teachers and parents need to know the child well. «To know the child is the most important point where the pedagogy theory and practice meet.» This is the basis for the creation of the people spiritual community, the success in the individual educating, when the meaning of education is reduced to its spiritual enrichment through creative human communication. Such upbringing makes him/her wise, sociable, tolerant and non-aggressive. 
If material needs are fully satisfied, a person will perceive the state of mind of others more acutely and compassionately. Such sophistication of her soul will be the key to human happiness (Sukhomlynsky, 2012).

Without human love and respect to pupils, there can be no upbringing. Reasonable love and respect make a child capable of being influenced by a teacher. According to Sukhomlynsky, to love a child is to give him/her what is valuable to yourself. ... «Without self-respect there is no moral purity and spiritual wealth of the individual» (Sukhomlynsky, 1977).

All the activity of the teacher was filled with the boundless faith in the child, the generosity and nobility of his/her soul, the inexhaustible wealth of intellectual and moral strength, the enormous educational opportunities that society creates. He wrote that the years of childhood were first of all the upbringing of the heart, which became its pedagogical meaning. Love for a child's heart is born in someone who is able to dispel anxiety and confusion, comfort, instill faith in their own strength; who is able to protect vulnerable, very sensitive children feelings i.e. a sense of dignity. He was convinced that empathy is a sensitive period in the formation of the child moral «I». Such moral concepts as: good and evil, justice and injustice, truth and lie, sincerity and selfishness, are manifested in the child's mind first and remain in children's emotional memories for life.

How to teach parents, to win the teachers' trust, openness, sincerity of the child, if it has not become a favorite for them are the rhetorical questions that the teacher himself/herself constantly thought over and demanded from his colleagues at Pavlysh school. It was unacceptable for him:

- to allow the child to be looked at as a monster;

- to be away from children's complaints, do not consider them slander, and all small complainants - «thin-tear slanderers. This is not always a true.

- to be able to listen to the child. This is a great pedagogical art. Where there is no such art, there is not and cannot be education;

- to be an example for training, self-education, have strong convictions, if you want to do this, but are not sure what not to do, never say: I give my word that I will do. Better say: I want to force myself to do this; I'll make myself to do just that. No matter how difficult it is, achieve your goal. Fulfill ten times, but make sure you are not ashamed in front of people;

- to bring up irreconcilability and intolerance to chatter, empty eloquence, crackling phrase, boastfulness. Let the habit of calling things by their names be transformed into character, into nature; 
- to strive for thought and word to be spiritualized by deeds and work, because everything in education is interconnected.

The family and the pupils group played an important role in this interaction (as the primary center). He believed that the individual and the team are two sides of the same coin. Without the education of the individual there can be no question of the collective as an educational force, and the education of the individual is inconceivable without self-education. He was convinced that self-education needs a very important, powerful stimulus as a sense of self-esteem and self-respect. The main purpose of this approach, according to V. Sukhomlynsky, is «to create a very tender, delicate thing: the desire to be good, to become better today than it was yesterday. But the desire to be good does not arise by itself, it can only be brought up when the child's soul is very sensitive to the tenuous, purely human means of influence such as a kind word, advice, kind look. There can be no question of self-education if the child is accustomed to rudeness and responds only to «strong» words, screams, compulsion. The essence of self-education involves trust in yourself and others, an appeal to honor and dignity.

Giving the priority to self-education, he saw first of all the relationship between teacher and pupil, filled with a deep mutual faith in good intentions. The teacher put a lot of pedagogical effort and experience to understand students' motive for their actions, behavior and actions. Contrary to the authoritarian approach, he put forward the idea of self-sufficiency of the individual in the conditions of collective education. The theory of education was dominated by the thesis «the team is always right» and the life of the individual must be completely subordinated to his interests. In contrast, V. Sukhomlynsky argued that the sensitivity of the individual to his/her own world of thoughts and feelings, self-respect, all this in certain circumstances require a limitation of the sphere of team influence on the individual»(Marusynets, 2018).

To bring up a person according to Sukhomlynsky means to breed in him/her demand to himself/herself. This is possible only when the grownup does not lead the child constantly by the hand, but allows him/her to act independently, to be responsible for himself/herself, to form his/her own life position.

What is the key in the education of personality in modern conditions? There are important dominants due to changes in the personality motivation. Today, the individual as an active subject of interaction must be motivated to work independently, to develop their own subjectivity in the context of meanings and values, the knowledge of which receives social networks, through the construction of their own program of education and self-development. The whole system of personal and collective 
communication must work for self-realization and self-development. The obvious potential and predictive role of V. Sukhomlynsky's pedagogical ideas about the system of group interaction of subjects on the way of the personality education as a member of society (micro and macro).

Educating the individual in the team, Sukhomlynsky made some warnings: is it possible to talk about the team as an individual educator, «if you do not understand all seriousness, where are the streams that fill the source of spiritual wealth of the team? A group of people becomes a disorganized crowd if everyone who communicates with their peers does not open up to them every day».

According to Sukhomlynsky, only those who can be a teacher, who has this vocation, believe in the power of education, can turn to the child's personality. To support the child, the teacher must feel the childhood, develop the ability to understand children and everything that happens to them, to treat their actions wisely, to believe that the child is wrong, not violating them intentionally; to protect it, not to think badly of it, unfairly, and, most importantly, not to break the individuality of the child, but to correct and direct his/her development, remembering that it is in a state of self-knowledge, self-affirmation, self-education.

The preschooler has already seen his/her «inner spiritual world», moreover, - «feels, understands, experiences the process of educational influence on himself». Therefore, penetration into the inner world of the child, a thorough study of the personality is possible if a real friendly relationship is established between the teacher and the pupil. Common interests are the strongest foundation. To get to know a child, the teacher must become a friend for her, not only to rejoice with him/her, but also to share grief; truly grieve for his/her fate. A child's trust to the educator can be compared to the thinnest, barely audible sound of a string when a musician's hand touches an instrument. ... «Figuratively speaking, in every child's heart there are tender, sensitive strings tuned to the perception of cheerful, bright music i.e. children's joys, creative work, friendship, brotherhood, society» (Free education of VLADI - VLADI: pedagogical almanac, 1993).

Knowing the psychology of the child, Sukhomlynsky wrote that the child's psyche is open, unprotected, vulnerable, so in the children's world cannot make the laws of the adult world, which are often unfair and cruel. Training teachers, he emphasized that the relationship between student and teacher should be based on interest and attention. Only in this case there will be real communication, and the child will hear his/her educator, feel the aspirations and follow them. 
Mentors in education are not only the school, but also the family, which is the primary center where the foundations of education are laid i.e. the tradition morals, behavior that requires great efforts. Such education, according to Sukhomlynsky, leads not only to the harmonious development of the children, but also to the self-determination of parents, the assertion of their human dignity. «There are dozens, hundreds of professions, specialties, jobs,» says the teacher, «one builds a railway, another builds a house, the third grows bread, the fourth treats people, the fifth sews clothes and the most universal, most difficult and noble work, one for all and at the same time, it is peculiar, unique in every family, it is a creation of the human» (Sukhomlynsky, 1976).

The teacher emphasized that no matter how responsible the work of the parents is at work, remember that at home you will have the same responsible, complex and delicate work as raising a child. We share the opinion of the teacher that everywhere you can replace a person with another employee, but no one will replace a real parent (Sukhomlynsky, 1976).

Realizing and understanding the inner world of the child, his/her experiences and feelings, V. Sukhomlynsky considered it as a mirror of the family, which reflects the spiritual world of father and mother. It is important for the family to have a relationship between parents and children based on kindness, openness, and respect. The main condition of such upbringing is the well-being of the family, which is its strong foundation, where prevails marital fidelity and love for children. In all his works, it is addressed the topic of human creation. His pedagogical credo is to teach people, to respect and love each other remains relevant through the centuries. «Human is created out of love i.e. the love of father to mother and mother to father; mother and father to people, deep faith in the beauty and dignity of man. It is important that parents create an atmosphere of respect and love for their children. He convinced them that wonderful children grow up in families where father and mother truly love each other and at the same time love and respect people. The teacher was able to read information about the family from the expression on the child's face: «I immediately see a child in whom parents deeply, heartily, beautifully, faithfully love each other. This child has peace and tranquility in the soul, deep mental health, sincere faith in the good, faith in human beauty, faith in the word of the educator» (Sukhomlynsky, 1976).

Sukhomlynsky assigned a special role in the upbringing of children to mothers. The success of each member depends on her ability to create relationships in the family, to preserve generational traditions. It is important that children have been brought up to have a noble attitude towards women 
as mothers. He started a wonderful tradition in the Pavlyshka school, which glorified the role of the mother that was «Mother's Day». In the fall and spring, students prepared for such a holiday by preparing gifts for their mother and grandmother. It was a common holiday that united everyone. The festivities began at the entrance to the school, where a board hung with the cherished words: «Mother, remember, you are the main teacher, the main educator. The future of society depends on you». No kindergarten, even the most ideal kindergarten or school, can replace the mother's school or overtake what the mother missed.

The tireless research work aimed at creating a favorable family environment helped Sukhomlynsky to find answers to numerous questions: why this or that child is excited, nervous, unbalanced; why its intellectual capabilities and interests are limited, where the roots of moral misfortune are hidden, etc. Some of them required the efforts of the teacher to persuade parents to change the style of education, especially authoritarian, unjustified prohibitions, physical abuse. He explained that if a child hears only prohibitions, it ties him/her, makes him/her shy, passive. He instructed on the demands of parents, emphasizing that the strictness should be expressed not only in prohibitions, but mainly in encouraging the child to take certain positive actions.

He was convinced that the authority of parents depends on many conditions, one of which is the correct, skillful use of parental authority. Parental authority is not only a right but also an art. Reflecting on the wisdom of maternal and paternal love, he identified their varieties. Here are the main ones in the characteristics of the meter of pedagogy of education. It:

1) love of admiration - where mother and father rejoice in every step of the child, without thinking about what step it is and what it can lead to. As a result, sons and daughters «sit on the neck» of parents, turn into little tyrants. A child who is brought up in the spirit of admiration does not know that in human coexistence there is the concept of «possible», «impossible», «necessary», it seems to him/her that everything is possible. Children's thoughts are especially destroyed in those cases when admiration is specially organized by adults, when children are turned into toys.

2) despotic love he described through the prism of anxious thoughts of parents: about a son who had a good heart as a child and was obedient; grew up and became rude, capricious. Why is this happening? I have been convinced a thousand times that the cause of this phenomenon is the inability of parents to exercise parental authority; that force is perceived and experienced by the child as an evil force that suppresses his/her will. 
Parental authority should encourage, inspire the inner spiritual strength of the child i.e. his/her desire to be good. This desire is almost in every child.

3) love of ransom. There are parents who sincerely believe that by fulfilling all the material needs of their children, they are fulfilling their parental responsibilities. Material costs, according to such parents, can measure parental love, in the worst case to pay off (moral and emotional thick-skinned, present to male parents).

The outstanding educator has identified a number of valuable practical tips for parents to create an atmosphere of full and harmonious development of the child in the family. Some of them deserve attention and have not lost their effectiveness in the current environment, when the institution of the family loses its functions and responsibilities to children. It:

1. Relationships in the family should be built so that even the smallest members are concerned with a sense of mutual duty, respect and care. Children should give someone a share of their soul from childhood, not to be closed in on themselves.

2. It is important to create such conditions that the child to his/her best abilities was the creator of good deeds for other people, especially for relatives. Particularly dangerous from the point of view of moral education is the individualism and consumer nature of young people lives in families, because it is where parents give their children everything and do not demand anything in return, people with stone hearts are egotists, lazy grow up people. «The family is the primary environment where a person must learn to do good» - these words of the teacher also became a well-known instructive aphorism. The pedagogical responsibility for the upbringing of the child should concern more with the parents. However, he did not take the responsibility for the child's upbringing from school. Emphasizing that the school educates and teaches, however, such work must be joint. The family and school must have a common approach to raising children, enabling them to develop harmoniously. Therefore, not only teachers but also parents must master the basics of education pedagogy.

3. The main «doctor» of all moral ailments is work. It becomes an effective means of education only if it is inspired by noble moral motives i.e. first external, which eventually grow into internal. The simplest motive is to bring joy to your family with your work.

The main dominants of parent-child relations according to Sukhomlynsky are: awareness that raising children is an honorable social duty; father and mother must be no less wise creators than teachers. In solving complex problems of education it is necessary to consider the individual approach and adhere to pedagogical tact; pedagogy should 
become a science for all, so much attention was paid to the organization of pedagogical education among parents.

He organized the parents' university at Pavlysh Secondary School, where parents enrolled two years before the child entered school and studied until he or she graduated. The course of study at the university was designed for 250 hours. The program covered all major sections of the theory of education and pedagogical psychology. Particular attention was paid to the characteristics of school age, personality formation, physical, mental, moral, aesthetic and professional education of children. Almost all parents (98\%) attended the university. The main goal of the university is to raise the level of family education culture (Sukhomlynsky, 1977).

\section{Conclusions}

Speaking about the uniqueness and predictability of the ideas of personality education, we note that the teacher-innovator was able in the totalitarian Soviet system to breed in children a sense of dignity, kindness and self-sufficiency. Based on the principles of humane pedagogy, he created a system of education that was radically different from the conventional, authoritarian, with the use of assessments and punishments. The relationship between students and teachers at Sukhomlynsky's school was built on the basis of: trust, humanity, kindness, respect for the child; no one should ever force a child to learn; to be a friend and mentor, to help understanding oneself, to develop the talent, to promote personal growth; to love people and nature, to see the surrounding beauty; invite parents to the school to encourage the child's actions; remember that a team becomes the children educator if it is formed in joy, respect, work.

A third of a century working at school has convinced the teacher that a child is best brought up when he raises others, cares about others. The whole teaching staff sought to ensure that in the years of adolescence, each pupil showed heartfelt care for a small child. Sensitivity, compassion, care for the child, these feelings are the noble emotional basis of the adolescent and youth team. Observing the students, he admired the filling of children's feelings that arose during joint activities.

In the conditions of the Sukhomlynsky era and nowadays, the educational effect of the team in different ages does not lose the levers of acquiring positive feelings, subject-subject interaction. The idea of interpersonal interaction in the conditions of school deficit, psychological bowling acquires special sharpness. According to statistics, $80 \%$ of Ukrainian children are bullied without even realizing it. Most of them, experiencing emotional problems, do not know how to build relationships 
with adults, peers, parents, teachers; have problems of psycho-emotional development. They already need the support of parents, teachers, and adults to help them to develop healthy relationships with both parents and peers. We find the answers to these questions in Vasyl Sukhomlynsky: a positive example of an adult who sees and imagines in his/her mind a child, a teenager, a young man who seeks self-realization, to achieve an ideal.

He introduced the concept of «protective education» in order to protect the child from evil, to create conditions to avoid loneliness. The main criteria for the choice was children who needed more attention from the teacher, a lack of love from the parents, as well as those who were complete irresponsible of action freedom. Among the components of such education Sukhomlynsky calls the education of self-esteem, compassion for people, understanding the beauty of nature. The very feeling of self-dignity, according to the scientist, directs a person to the good, keeps from immoral acts.

He was against punishment. If a child is brought up in tenderness, kindness, understanding, especially adolescents, then no punishment is required. It is important to teach him/her to control the emotions; help to understand, evaluate and develop the correct worldview, volitional qualities of the child's personality, and then the problem of difficult adolescents will disappear. He urged parents not to neglect the child, as this can lead to negative educational consequences, aggression, violation, cruelty. «Strong» means of influence frees the child from thoughts, considerations, reflections; he/she experiences not the shameful act, but punishment; it essentially forgets about a bad deed, and the logic of upbringing is that the child thinks about it, thinks, and it turns out that the child thinks badly. He/she thinks of herself as offended; anger accumulates in her heart. In addition, if there is even a drop of injustice in the punishment, then an avalanche of anger threatens a strong, unexpected collapse for the teacher.

He considered children's experiences as the basis of the values of the growing personality. According to traditional educational methods, the teacher must monitor the flow of emotions of the child and in time to resort to prevention and correction. Emphasizes the cultivation of We-experiences that produce emotional integrity, harmonious relationship between teacher and student. This spiritual unity contributes to personal development. It occurs when a child wants to help his elder persons. Adults should not interfere with these intentions, but take them seriously. The child should form emotional judgments such as: «we work», «we are busy», «it's hard for us», «we are tired», «we rest».

Thus, the educational process serves to help the child, in which the teacher preserves the inner subjective integrity of the pupil, stimulates 
him/her to spiritual and moral self-improvement. It hurts even to think that in schools we still have some students who carry undivided grief, which dries the heart, devastates the soul. My heart aches, the educator wrote, when I see a gloomy teenager who is closed in himself/herself. The most terrible grief is the feeling of inferiority: knowledge is given to others, but nothing works for me, I am a loser, this is my destiny ... This grief accumulates gradually, day by day, it painfully compresses the heart, binds the soul with cold. The teenager wants to share his grief, but he is ashamed and he is silent. He is silent at home, silent at school. Therefore, it is necessary to look closely at such children and to help them to get rid of an unbearable burden. It is important to bring them joy, help them believe in themselves, see their success in mastering knowledge and experience this feeling of pride. Awareness of the pupil of his own formation; understanding and experiencing what I can - a wonderful motivation to realize my own development - dignity, experiencing a sense of self-esteem. Only where the pupil respects himself, self-education is possible. And the deeper the feeling of self-esteem, the more sensitivity, receptivity to your moral teachings, to your instructions: you need to educate yourself like this. Where there is no self-esteem, the person is completely deaf to your teachings and advice. Selfesteem does not tolerate rude, «strong», «strong-willed» means. Sukhomlynsky called self-esteem a child's intelligence, by which he meant mental weekness, multiplied by the purity of thoughts, desires, intentions. Here we are dealing with the most interesting thing in school, which deserves great attention, but, unfortunately, little studied i.e. with children's mental work, or rather, with the reflection of this work in the emotional sphere and with intellectual feelings. Self-respect is born of bright intellectual feelings as the joy of knowledge. In these intellectual feelings is the source of children's intelligence. If upbringing is accompanied by gloomy feelings, the child becomes indifferent to himself i.e. there can be no question of any selfeducation. The most important educational task of a teacher as an educator is to protect the light of bright intellectual feelings in a child's heart, not to let them go out, it is very difficult to highlight them again.

Sukhomlynsky imagined the right upbringing as follows: a child does not allow serious bad deeds, and small, insignificant «sins» he/she deeply experiences, takes to heart, feels remorse, this is the most important thing. The art of parenting is to prevent serious misconduct through individual conversations with the child. Such conversations should be conducted carefully, gently touching the child's heart, be tender, the most careful. Only tenderness and caution motivates the child to talk, to reveal the secrets. Training teachers, he emphasized to keep the secret that the child has 
entrusted to you and this is one of the basic rules in pedagogy of upbringing and self-education.

The main dominant in the pedagogy of Sukhomlynsky's upbringing is the golden rule: the like is brought up only by the like: love is love, demand is by demand, kindness is by kindness.

Through the prism of the dialogical principle, the teacher considered the moral sphere of the individual. This forced him to critically analyze the spiritual world of the individual.

Awareness of education as an important act, a complex work that gives rise to man, requires the teacher to be professionally and morally prepared for this.

In the article «Years of Adolescence - Second Birth» (1966), which is called the mature work of a teacher, we find prophetic words, which laid the deep educational meanings of the human and humane. Their highest engine is human behavior, which is metaphorically called «the king in the head.» Its essential characteristics are - experience and moral values. All these take possession of the consciousness of the pupil only when, in addition to understanding good and evil, in addition to logical analysis - that good and bad, in the soul lives a feeling, the experience of good and evil. «The king in his head becomes a powerful leader only if, communicating with people, feeling an active participant in human relations, a person experiences good and evil, good and bad outside his/her face, as good and bad in himself» (Etudes about Pedagogical Apocrypha: Scientific-Popular Publishing House, 2008).

Reflecting on the inner world, comparing it with the ideals of the spiritual culture of previous generations, the teacher fills it with a new meaning «personality» as an inexhaustible whole (moral, intellectual, emotional, creative).

Creating a person for a full life should be the main common goal of the teacher, parent and child. Belief in the power of education did not leave him throughout his teaching career. He was convinced that the success of education depends on a deep penetration into the spiritual world of the student «... Three thousand seven hundred pages in the notebooks that I lead all my teaching life ... Each page is dedicated to one person - my student. Three thousand seven hundred educational destinies. Here is almost the entire adult population of our village. Recently, I wanted to turn these pages ... Each child was a special, unique world». Sukhomlynsky noted that the teacher is obliged to know this world, because the process of education is expressed in the unity of their ideals, interests, thoughts, experiences. 
Harmony of pedagogical influences is the main component of the education. «Any influence on the individual loses its force if there are not hundreds of other influences,» wrote V. Sukhomlynsky.

As we can see, the pedagogical world of V. Sukhomlynsky is complex and diverse. It has constantly understood by scientists and educators of the new era. To deeply understand the teacher-thinker, it is necessary to rise above his professional impulses, to comprehend the depths of his humanistic worldview, which culminated in the pedagogy of higher wisdom i.e. the wisdom of education. His life was filled with joys and sorrows, hopes and disappointments, creative prospects and self-dissatisfaction. Educational dominants identified by an outstanding teacher are waiting for their researcher, teacher, reader for their implementation in the educational process.

\section{References}

Marusynets M. M., Makarenko L.L. (2019) Vasyl Sukhomlynskyi and the professional teacher's development. Scientific journal of M. P. Drahomanov National pedagogic university. Part 5. Pedagogical sciences: realis and prospects. Volume 69 (Index Copernicus).

Marusynets, M. M. (2018) Vasyl Sukhomlynskyi on labor education: modern context of the comprehension. Scientific journal of M. P. Drahomanov National pedagogic university. Part 5. Pedagogical sciences: realis and prospects. Volume 63.

Sukhomlynsky V. O. (1976) How to raise a real person. Kyiv.

Sukhomlynsky V. O. (2012) Selected works. Kyiv: Osvityanske slovo.

Sukhomlynsky V. O. (1977) I give my heart to children. Selected works: in 5 volumes. Kyiv.

Sukhomlynsky V. O. (1977) Birth of a citizen. Selected works: in 5 volumes. Kyiv.

7. Free education of VLADI - VLADI: ped. almanac / ed. V. M. Blinov, G. B. Cornets. Moscow: [b.i], 1993. Vol. 3 (March-April) -- 65 p.

Etudes about V.A. Sukhomlynsky. Pedagogical apocrypha: scientific-popular edition / comp., Preface, afterword, commentary, introduction. to parts of the book $O . V$.

Sukbomlynskaya. Kharkiv: Akta, 2008. 